\title{
Jaruzelonostalgia? Wizerunek lat osiemdziesiątych w polskim kinie najnowszym (2007-2017)
}

\begin{abstract}
Streszczenie
Artykuł dotyczy sposobów ukazywania dekady lat osiemdziesiątych w polskim kinie najnowszym (w okresie 2007-2017). Autor wskazuje na cztery podstawowe kategorie filmów dotyczących ostatniej dekady PRL-u: „,wielkie biografie” dotyczące kluczowych postaci historycznych, takich jak: Lech Wałęsa, Jerzy Popiełuszko czy Ryszard Kukliński; „małe biografie”, odnoszące się do losów osób powszechnie znanych, ale działających poza sferą polityczną, takich jak Zbigniew Religa czy rodzina Beksińskich; „filmy rozrachunkowe”, w których dekada stanu wojennego jest ukazana jako okres przede wszystkich różnego typu wyborów o charakterze polityczno-etycznym, które w taki czy inny sposób oddziałują na czasy współczesne. Ostatnią grupę można nazwać „filmami o codzienności”, odnoszą się one bowiem do „dekady Jaruzelskiego”, jednak pokazują ją nie od strony uwikłania w procesy historyczno-polityczne (choć w większości filmów odgrywają one rolę w życiu bohaterów), ale od strony problemów dnia codziennego.
\end{abstract}

\section{Słowa kluczowe:}

lata osiemdziesiąte, historia, postaci historyczne, film polski, nostalgia

\begin{abstract}
The article concerns the ways of displaying the decade of the eighties in the Polish newest cinema (in the period 2007-2017). The author points to four basic categories of films about the last decade of the PRL: "great biog-
\end{abstract}

1 Arkadiusz Lewicki, Wydział Filologiczny, Uniwersytet Wrocławski, Polska, e-mail: arkadiusz. lewicki@uwr.edu.pl, ORCID ID: https://orcid.org/0000-0003-0484-2849. 
raphies” on key historical figures such as Lech Wałęsa, Jerzy Popiełuszko or Ryszard Kukliński; “Small biographies” referring to the history of wellknown people but operating outside the political sphere, such as Zbigniew Religa or the Beksiński family; "Settlement films”, in which the decade of martial law is shown as a period of, above all, various types of political and ethical choices that in one way or another affect modern times. The last group can be called "films about everyday life", because they refer to the "Jaruzelski's decade", but they show it not from the side of entanglement in historical-political processes (although in most films they play a role in the characters' lives), but from the everyday problems.

\section{Keywords:}

eighties, history, historical figures, Polish film, nostalgia

\section{NOSTALGIA ZA LATAMI OSIEMDZIESIĄTYMI}

Rafał Syska rozpoczyna artykuł Reaganomatoretro, czyli czekajq̨c na herosa od znamiennych zdań: „W każdej epoce kiełkują osobne ziarna nostalgii i dojrzewają wtedy, gdy teraźniejszość - zamiast ukojenia - budzi niepokój i rozczarowanie. W kinie chętnie odtwarzamy przeszłość w rytuałach zawartych w poetyce retro-melancholijnej, sztucznej i martwej jednocześnie” (2012, s. 15). Dalsza część tekstu poświęcona jest przede wszystkim latom osiemdziesiątym w amerykańskiej kinematografii, kiedy to, jak twierdzi badacz, dało się zauważyć bardzo wyraźny zwrot do kultury i sztuki z lat pięćdziesiątych, czasów prezydentury Dwighta Eisenhowera. W poetyce i przesłaniu kina czasów Reagana Syska dostrzega tęsknotę za prostymi, westernowymi receptami rozwiązywania konfliktów, za herosami o niezłomnym charakterze, nobilitację wartości amerykańskiej prowincji. Jednocześnie - jak twierdzi autor - w kinie najnowszym można z kolei obserwować zwrot w stronę kinematografii z epoki końca zimnej wojny. Radosny powrót najważniejszych aktorów kina akcji tamtej dekady w filmach z serii o charakterystycznym tytule Niezniszczalni (The Expendables, reż. Sylvester Stallone; 2010, reż. Simon West, 2012; Patrick Hughes, 2014) czy sukces superbohaterów spod znaku Marvela czy DC to dla Syski dowody na powrót do ideologii kina lat osiemdziesiątych. Artykuł pisany był w roku 2012, autor nie mógł więc przewidzieć nie tylko zwycięstwa Donalda Trumpa, ale i niezwykłej popularności seriali, takich jak Stranger Things (2016) czy Dark (2017), które nie tylko rozgrywają się w przedostatniej dekadzie XX wieku, ale także odwołują się do poetyki i ideologii (choć wziętej w nostalgiczny cudzysłów) filmów z tamtego okresu. Pewną 
symboliczną klamrę pomiędzy oddzielonymi o trzydzieści lat dekadami tworzą być może kolejne adaptacje powieści grozy Stephena Kinga To (It), który „opisał w niej - na przemian - losy kilkorga dzieci, które w 1958 roku muszą zmierzyć się z przyjmującym różne postaci złem, i działania ich samych jako dorosłych, którzy - przywołani dziecięcym przyrzeczeniem - wracają do rodzinnego miasta, by dokończyć tę walkę” (Syska, 2012, s. 16). Pierwsza adaptacja pochodzi z roku 1990 i ma formę dwuodcinkowego miniserialu telewizyjnego w reżyserii Tommy’ego Lee Wallace’a, którego akcja (co też znamienne) w retrospekcjach została przeniesiona do lat sześćdziesiątych. Z kolei w filmie w reżyserii Andresa Muschiettiego (2017) akcja retrospektywna toczy się w latach 1988-1989, choć dorośli bohaterowie spotykają się po 28 latach (tyle bowiem czasu potrzebuje mityczne zło, by się odrodzić).

W tym wymyślonym przez Kinga cyklu zawarta jest ogólna prawidłowość dotycząca nostalgicznych powrotów do kolejnych dekad, które stawały się popularne w okresach odpowiadających mniej więcej pokoleniowej wymianie.

Nie powinno więc nas dziwić, że w dekadzie 2007-2016 zaczęły pojawiać się w Polsce filmy odwołujące się do lat osiemdziesiątych właśnie, choć (przynajmniej pozornie) nie są to czasy, które powinny w naszym kraju budzić jakąkolwiek tęsknotę. Choć początek („festiwal Solidarności”) i koniec dekady (pierwsze na wpół wolne wybory i początek przemian ustrojowych) to momenty niosące nadzieję, jednak znakomita większość tego okresu to czas nasilenia politycznych represji, wszechobecnej cenzury i inwigilacji, ekonomicznej nędzy, powszechnego zniechęcenia wobec szarej rzeczywistości. Wydarzeniem, zapewne w największym stopniu wpływającym na tę dekadę, było wprowadzenie stanu wojennego, które nastąpiło 13 grudnia 1981 roku, kiedy to władzę przejęła Wojskowa Rada Ocalenia Narodowego z generałem Wojciechem Jaruzelskim na czele. „Na mocy Dekretu o stanie wojennym, rozporządzeniami datowanymi na 12 i 13 grudnia zawieszono działalność wszystkich stowarzyszeń i związków zawodowych, zakazano organizowania strajków i akcji protestacyjnych, zwoływania wszelkiego rodzaju zgromadzeń i manifestacji. Zawieszono działalność kin, teatrów i wydawanie prasy. Zmilitaryzowano kolej, pocztę, służbę zdrowia i wiele innych zakładów pracy, powołano do czynnej służby wojskowej dużą liczbę rezerwistów. Zakazano poruszania się obywatelom w miejscach publicznych od godziny 22.00 do 6.00 (godzina milicyjna). Zawieszono łączność telefoniczną i teleksową, wprowadzono cenzurę przesyłek pocztowych. Zawieszono międzynarodową i krajową komunikację lotniczą” (Gluza, 2014, s. 303-304). Wprowadzenie stanu wojennego to także akcje pod kryptonimem „Azalia”, polegająca na przejęciu łączności i obiektów Radia i Telewizji, oraz „Jodła”, zakładająca internowanie najważniejszych działaczy 
politycznych związanych z szeroko pojętą opozycją. Z innych istotnych efektów nocy z 12 na 13 grudnia można na przykład wymienić trzykrotny wzrost czarnorynkowej ceny dolara („,z 480-520 zł do 1500-1600 zł”) (Gluza, 2014, s. 305), który bardzo dobrze obrazuje zarówno społeczny niepokój, jak i ekonomiczne konsekwencje wprowadzenia stanu wojennego, który, choć formalnie zakończył się 22 lipca 1983 roku, to jednak wywarł wpływ na całą dekadę.

O ile więc można bez większego trudu zrozumieć amerykańską nostalgię za czasami rządów Ronalda Reagana, o tyle polska ,jaruzelonostalgia” jest do zrozumienia nieco trudniejsza, a przecież w ostatniej w latach 2007-2016 powstało w Polsce prawie 20 filmów, które w większym lub mniejszym stopniu odnoszą się do czasów, gdy niepodzielne rządy sprawował ,generał w ciemnych okularach”. Co warte zauważeni - polska „nostalgia” nie przybiera formy, którą Kaja Klimek określiła mianem „wirusa sequelitis” (2012, s. 5), który opanował kino amerykańskie. Pomimo tego, że w latach osiemdziesiątych pojawiło się wiele tytułów, które cieszyły się wielką popularnością wśród ówczesnej widowni, to w omawianej dekadzie nie doczekaliśmy się ani jednego filmu, który byłby kontynuacją któregoś z przebojów lat osiemdziesiątych, a jedynie jednego (bardzo mocno uwspółcześnionego) remaku - filmu Piotra Wereśniaka Och Karol 2 (2011), nawiązującego do komedii Romana Załuskiego z 1985 roku. Nostalgia za przedostatnią dekadą XX wieku nie ma więc wymiaru ekonomicznego, nie bazuje na chęci zysku producentów, którzy próbują przyciągnąć do kin widzów pamiętających oryginał sprzed kilku dekad i chcących porównać go z nowszą wersją.

Wydaje się, że utwory nakręcone w latach 2007-2017, a dotyczące w mniej lub bardziej bezpośredni sposób lat osiemdziesiątych, można podzielić na kilka podstawowych kategorii. Pierwszą z nich określa się mianem „wielkich biografii”, obejmują bowiem opowieści o postaciach kluczowych dla polskiej historii tamtego okresu. Drugą grupę tworzyłyby filmy, które określiłbym mianem „małych biografii”, odnoszą się bowiem do osób, które są powszechnie znane, lecz ich losy związane są raczej z historią pisaną z małej, a nie wielkiej litery. Trzecią grupę tworzyłyby „filmy rozrachunkowe”, w których dekada stanu wojennego jest ukazana jako okres przede wszystkich różnego typu wyborów o charakterze polityczno-etycznym, które w taki czy inny sposób oddziałują na czasy współczesne. Ostatnią grupę nazwać można „filmami o codzienności”, odnoszą się one bowiem do „dekady Jaruzelskiego”, jednak pokazują ją nie od strony uwikłania w procesy historyczno-polityczne (choć w większości filmów odgrywają one rolę w życiu bohaterów), ale od strony problemów dnia codziennego. 


\section{WIELKIE BIOGRAFIE}

W tej kategorii, w moim odczuciu, mieściłyby się trzy filmy zrealizowane w ciągu ostatnich kilku lat, których akcja rozgrywa się na pograniczu lat siedemdziesiątych i osiemdziesiątych. Są to utwory mówiące o Lechu Wałęsie - Wałęsa. Człowiek z nadziei (2013) Andrzeja Wajdy; księdzu Jerzym - Popiełuszko. Wolność jest w nas (2009) Rafała Wieczyńskiego i Jack Strong (2014), Władysława Paskikowskiego, przypominający postać Ryszarda Kuklińskiego. Niewątpliwie wszystkie te postaci odcisnęły istotne piętno na polskiej historii lat osiemdziesiątych, a poświęcone im utwory wzbudziły kontrowersje związane choćby z wiernością „prawdzie historycznej”. Krzysztof Kornacki na przykład zarzucał Wajdzie, że w swoistej trylogii, którą tworzą Człowiek z marmuru (1976), Człowiek z żelaza (1981) i Człowiek z nadziei dostrzec można „narastającą autorską tendencję do urealniania fikcji filmowej w znaczeniu, w którym fikcja zaczyna być traktowana jak rzeczywistość, jej ekwiwalent. Działo się tak poprzez zacieranie granic pomiędzy fikcją historyczną a faktografią i zastępowanie tego, co faktyczne - tym, co zmyślone. Obok tych zabiegów pojawiła się w trylogii tendencja do wzmacniania wiarygodności fikcyjnej opowieści poprzez użycie materiałów dokumentalnych. Stopniowe przemiany dokonywane w sferze artystycznej sprzężone były z publiczną działalnością reżysera, w której przekraczał on stopniowo granice sztuki w stronę już nie tylko społecznej, ale też politycznej praxis” (2017, s. 78). Z kolei filmowej biografii księdza Jerzego Popiełuszki zarzucano, że jest nudna i szablonowa. Na przykład Rafał Świątek tak pisał o tym filmie w „Rzeczypospolitej”: „Fabuła obrazu Wieczyńskiego jest przykładem, jak nie należy robić filmu. Przypomina zlepek plakatowych, byle jak zainscenizowanych sekwencji. Mały Jerzy na grzybach jest świadkiem polowania na antykomunistyczne podziemie. Popiełuszko seminarzysta odbywa pełną upokorzeń służbę wojskową. Pierwsza pielgrzymka papieża do kraju. Porozumienia sierpniowe. Stan wojenny. Demonstracje przeplatają się z mszami za ojczyznę. Mord na księdzu Jerzym. Koniec. Oglądając ten ciąg zdarzeń, miałem wrażenie, że Wieczyński pośpiesznie wertował biografię Popiełuszki na przemian z podręcznikiem do historii Polski, próbując stworzyć scenariusz. Z takiej lekcji młodzi ludzie nie wyniosą więcej niż z wykładu prowadzonego z rozsypanych notatek przez nudnego belfra” (2009). Z kolei filmowi o pułkowniku Kuklińskim zarzucano powierzchowność i brak należytego rozwinięcia poszczególnych wątków. Jak pisał recenzent „Newsweeka”: „Autorzy scenariusza - zdecydowali się pójść po łebkach i pokazać jak najwięcej, a do tego zmieścić się w mniej niż dwóch godzinach. Pod względem cięcia wątków film jest więc niezwykle udany. Tyle że w efekcie pozostaje duży niedosyt, bo żaden 
z głównych elementów fabuły nie zostaje należycie rozwinięty” (Orzechowski, 2016). Jednocześnie kilku recenzentów zwróciło uwagę, że z różnych wątków pojawiających się w filmie „najsłabiej wypada wątek rodzinny” (Orzechowski, 2016). Co charakterystyczne wątkom rodzinnym sporo uwagi poświęcają także osoby piszące o filmie Wajdy. Scenarzysta filmu, Janusz Głowacki, pisze na przykład, że po ukazaniu się książki żony Wałęsy - Wajda był „wyznaniami pani Danuty poruszony i zaniepokojony” (2013, s. 98). Pojawiło się w niej bowiem „porażające grozą wyznanie. [Wałęsa - A.L.] Nie prał, nie gotował, nie zmywał naczyń, nie wyrzucał śmieci, nie troszczył się o dzieci, nie robił zakupów, tylko palił, strajkował i dzieci robił” (2013, s. 98). Dlatego, jak pisze Mirosław Przylipiak (2018), postanowiono „ocieplić” wizerunek przywódcy Solidarności, stąd też wzięły się w filmie sceny pokazujące w sposób nieco bardziej pogłębiony relacje małżeńskie, choćby „scena z jajecznicą”, podczas której Lech, widząc rosnącą irytację żony, wygania z mieszkania kłębiących się w nim korespondentów zagranicznych. Jednak nawet te sceny nie zmieniają ogólnego obrazu rzeczywistości lat osiemdziesiątych. W filmach reżyserów (urodzonych, co warto podkreślić, w roku 1926 - Wajda, 1959 - Pasikowski i 1968 - Wieczyński) historię tworzą mężczyźni. A rolą kobiet jest wspomaganie ich w ich walce, dbanie o dom i dzieci oraz troszczenie się o rodzinę.

\section{MAtE BIOGRAFIE}

Bardzo podobnie wygląda rola kobiet w filmach, mieszczących się w kategorii, którą określiłem mianem „małych biografii”. W dziełach: 80 milionów (2011) Waldemara Krzystka, Bogowie (2014) Łukasza Palkowskiego czy Ostatnia rodzina (2016) Jana P. Matuszyńskiego opowiadających odpowiednio historię wywiezienie z banku w przeddzień stanu wojennego związkowych pieniędzy przez wrocławskich działaczy Solidarności, walki Zbigniewa Religii o dokonanie pierwszego w Polsce przeszczepu serca i skomplikowanych relacji łączących rodzinę Beksińskich - kobiety pojawiają się w tle, kamera skupiona jest bowiem niemal wyłącznie na działaniach męskich protagonistów. Warto podkreślić, że można dostrzec jednak pewne różnice w portretowaniu tych drugoplanowych bohaterek. W filmie Waldemara Krzystka (rocznik 1953) kobiety zdają się być w pełni podporządkowane patriarchalnemu porządkowi. Czekają na swoich mężów i narzeczonych, są dla nich ostają i bezpieczną przystanią, wpisując się w stereotyp „wiernej Penelopy” lub „nagrody dla znużonego wojownika”. Walcząc zaś po drugiej stronie barykady - jak udająca francuską dziennikarkę Natalia (Emilia 
Komarnicka-Klynstra), która w rzeczywistości jest agentką SB - nie wahają się użyć swych kobiecych wdzięków w celu zdobycia potrzebnych informacji.

W biografii Zbigniewa Religii kobiety również pojawiają się na drugim planie, na który w latach osiemdziesiątych były niewątpliwie zepchnięte. Jednak Łukasz Palkowski (rocznik 1976) zdaje się już zauważać, jak niedoceniona była ich rola. Z jednej strony pojawiają się w Bogach zastępy pielęgniarek, pomijane i niedoceniane w historii medycyny, a pełniące niezwykle znaczącą rolę - w wielu momentach filmu można odnieść wrażenie, że bez ich zaradności, zdrowego rozsądku i troski genialni lecz nieco oderwani od życia lekarze w ogóle by sobie nie poradzili w najprostszych sytuacjach. Z drugiej strony w filmie widzimy też dramat żony głównego bohatera, granej przez Magdalenę Czerwińską. Anna Religa ma świadomość, że jej mąż jest świetnym lekarzem, próbuje wspierać go w jego zamierzeniach, lecz w wielu scenach ukazane jest jej rozdarcie i pewna toksyczność relacji, w którą jest uwikłana. Co ważne, w filmie nakręconym przez reżysera o dwie dekady młodszego od twórcy 80 milionów nie tylko nieco inaczej ukazane są relacje genderowe, ale i polityka odgrywa zdecydowanie mniejszą rolę. Oczywiście związane jest to zapewne z tematem poruszanym przez oba filmy, ale ta prawidłowość będzie powtarzać się przy omawianiu kolejnych utworów dotyczących Polski lat osiemdziesiątych. Im młodsi bowiem będą twórcy (choć pojawią się od tej reguły wyjątki), tym kontekst polityczny lat, o których opowiadają w swoich utworach, będzie odgrywał mniejszą rolę. W Bogach Religa (Tomasz Kot) musi się co prawda zmagać z ograniczeniami budżetowymi, z niedostatkami ekonomicznymi „realnego socjalizmu”, z zacofaniem decydentów, ale wydaje się, że nie ma wymiaru ideologicznego. W tej skrojonej według najlepszych wzorców amerykańskiego kina gatunkowego biografii wybitnej jednostki pojawiają się tępi funkcjonariusze aparatu władzy, ale ich ideologiczna przynależność zdaje się mieć zdecydowanie drugorzędne znaczenie. Ograniczeni, bezduszni biurokraci pojawiali się przecież niezwykle często również w hollywoodzkim kinie lat osiemdziesiątych. Potwierdzałoby to w pewien sposób tezę, którą w Kulturowych sprzecznościach kapitalizmu głosił Daniel Bell, nazywając sowiecki komunizm rodzajem „kolektywizmu biurokratycznego” (2014, s. 20), a która to teza zdaje się (w sposób niezbyt uświadomiony zapewne) stać za najnowszymi obrazami przeszłości kreowanymi przez młodszych twórców, którzy uznają czasy PRL-u za przeszłość, w której oczywiście ideologia socjalistyczna odgrywała pewną rolę, ale była jedynie częścią rozleglejszego systemu dominacji „świata białych mężczyzn”, który przybierał nieco odmienne formy po obu stronach „żelaznej kurtyny”, ale w swojej istocie był niezwykle podobny.

Potwierdzeniem tej tezy byłoby uważniejsze przyjrzenie się Ostatniej rodzinie Jana P. Matuszyńskiego (rocznik 1984). W tej historii rodziny Beksińskich komuni- 
styczny system, w którym przyszło im egzystować, stanowi jedynie trzeciorzędne tło. Znacznie istotniejsze są problemy psychiczne bohaterów, ich indywidualne dziwactwa, natręctwa, neurozy. Lata osiemdziesiąte (w których rozgrywa się znaczna część akcji) to jedynie dodatek - szare blokowisko, małe zagracone mieszkanko z wielkiej płyty, rozlatująca się winda - tworzące tło dla rodzinnego dramatu, w którą pozornie drugorzędną, ale niezwykle istotną rolę odgrywa Zofia Beksińska (Aleksandra Konieczna) - kobieta, która równoważy „dwubiegunowy ekscentryzm męskiego duetu” i jest „stonowana, wycofana, oddana, poświęcająca siebie na ołtarzu macierzyńskiej i małżeńskiej miłości. Być może [jest to - A.L.] najciekawsza postać filmu - właśnie przez tę migotliwość, niespełnienie. Współczująca i budząca współczucie” (Popielecki, 2016).

\section{FILMY ROZRACHUNKOWE}

Nieco inny obraz rzeczywistości znajdziemy w filmach, które nazwałbym „rozrachunkowymi”. Można je podzielić na dwie kategorie. Pierwsza obejmowałaby utwory, w których znaczna część akcji rozgrywa się w latach osiemdziesiątych. Wśród nich można wymienić Obywatela (2014) w reżyserii Jerzego Sthura, będącego swoistą kontynuacją filmu, w którym reżyser zagrał niegdyś główną rolę, czyli Obywatela Piszczyka (1988) Andrzeja Kotkowskiego, będącego z kolei sequelem filmu Andrzeja Munka Zezowate szczęście (1960). Nie jest to jednak sequel w klasycznym tego słowa rozumieniu, bowiem filmy Kotkowskiego i Munka stanowiły dla Sthura raczej rodzaj inspiracji, szczególnie dla postaci głównego bohatera, niż żródło powiązań fabularno-formalnych. Po raz kolejny okazuje się, że starsi autorzy (Jerzy Sthur urodził się w roku 1947) widzą przedostatnią dekadę XX wieku przede wszystkim przez pryzmat dominujących wówczas wydarzeń politycznych. Jan Bratek (grany przez reżysera i Macieja Sthura) jest kolejnym „człowiekiem bez właściwości”, który na skutek niefortunnych zbiegów okoliczności wikła się w wielką Historię. Choć jest pełen dobrych chęci i marzy tylko o podróżowaniu, to wciąż wplątuje się w sytuacje skazujące go na udział w kolejnych wydarzeniach politycznych, zarówno w okresie stanu wojennego, gdy przypadkowo zostaje internowany, a potem żeni się z Renatą, więziennym psychologiem, która okazuje się (z czego w swojej naiwności Jan nie zdaje sobie sprawy) oficerem SB, jak i w okresie Polski niepodległej. Jednak lata osiemdziesiąte w filmie Sthura to okres wypełniony niemal w całości opozycyjną walką (nawet jeśli nie wynikała ona ze świadomych decyzji podejmowanych przez bohatera), choć również czerpaniem z niej (głównie seksualnych) profitów. Po raz 
kolejny okazuje się, że - przynajmniej według reżyserów tworzących omawiane filmy - Polki w tej dekadzie marzyły tylko o tym, by oddać się ciałem i kuchnią jakiemuś dzielnemu opozycjoniście, jak czyni to choćby filmowa Kazia (Violetta Arlak), ukrywająca Bratka w swoim mieszkaniu.

Nieco inny charakter ma ostatni film w dorobku Janusza Morgensterna (1922-2011) zatytułowany Mniejsze zło. Z jednej strony z pietyzmem zostały w nim odwzorowane realia lat osiemdziesiątych, z drugiej okazuje się, że w oczach scenarzysty (Janusz Anderman, urodzony w roku 1949) i reżysera była to epoka niemal w całości podporządkowana polityce. Zdają się oni w pełni podzielać zdanie Jacka Łukasiewicza, który w artykule zamieszczonym w tomie Artyści a służba bezpieczeństwa: pisał: „Twórca w Polsce Ludowej podlegał trzem współzależnym, lecz rozmaicie kształtującym się porządkom: ideologicznemu, administracyjnemu oraz, nazwijmy to, represyjno-kontrolnemu. Wszystkie składały się na jeden system” (2008, s. 14). Główny bohater filmu Morgensterna - Kamil Nowak (Lesław Żurek) - to debiutujący pisarz - student polonistyki. Całe jego życie zdaje się być „problemem politycznym”, opublikowanie kolejnego wiersza, zdanie egzaminu, wcielenie do wojska, nawet rodzinne rozmowy, wciąż oscylują wokół konieczności opowiedzenia się po którejś ze stron politycznego konfliktu, dokonania ważkiego wyboru między poparciem a przeciwstawieniem się komunistycznej władzy. Z drugiej strony - i być może to właśnie jest najciekawszym aspektem tego utworu - według autorów Mniejszego zła bycie opozycyjnym poetą w latach osiemdziesiątych było potężnym feromonem przyciągającym do bohatera wręcz tabuny kobiet. Atrakcyjne koleżanki ze studiów, które podrywa, chwaląc się znajomością z Tadeuszem Konwickim, zafascynowana jego twórczością piękna Aktorka (Magdalena Cielecka), Eseistka (Edyta Olszówka) pragnąca ze wszystkich sił pomóc przystojnemu literatowi, nawet należąca do Partii dyrektorka szpitala psychiatrycznego, w którym ukrywał się przed powołaniem do wojska - wszystkie one lgną do tworzonej przez Nowaka legendy buntownika przeciwstawiającego się władzy i nie szczędzą mu swych wdzięków. Lata osiemdziesiąte w filmie Morgensterna są więc okresem na wskroś politycznym, a jednocześnie czasem dominacji patriarchalnego wzorca, wedle którego „niezłomny wojownik walki za sprawę” mógł liczyć na „wsparcie niewiast” oraz na swobodny i ochoczo przyznawany „dostęp do ich alków”.

Innym filmem o rozrachunkowym charakterze byłaby, w moim odczuciu, Zwerbowana miłość (2009) Tadeusza Króla. Akcja tego obrazu rozgrywa się w ostatnich latach omawianej dekady, gdy było już jasne, że komuniści utracą władzę, a działacze partyjni i oficerowie SB próbowali jakoś „urządzić się w nowej rzeczywistości”. Andrzej (Robert Więckiewicz) uwodzi i angażuje w swój plan 
dziewczynę lekkich obyczajów (Joanna Orleańska), która ma wydostać dla niego i jego kompanów dokumenty zdeponowane w wiedeńskim banku. Z jednaj strony film ten przynosi nieco sentymentalny obraz końca lat osiemdziesiątych, z dość skrupulatnie odtworzonymi strojami, fryzurami, wystrojem wnętrz i obyczajowością tamtego okresu, a jednocześnie przesycony jest wątkami politycznymi. Niemal wszyscy męscy bohaterowie filmu to twardzi i skorumpowani esbecy, niemal wszystkie kobiety to prostytutki i ten podział oddaje nie tylko patriarchalny sposób funkcjonowania ówczesnego społeczeństwa, widoczny jeszcze choćby w „kinie bandyckim” z lat dziewięćdziesiątych, ale i wpisuje się w opowieść o czasach transformacji jako o okresie „uwłaszczenia nomenklatury” i członków komunistycznego aparatu bezpieczeństwa.

Z przyczajonymi, a jednak odgrywającymi wciąż istotną rolę oficerami dawnych służb spotkamy się także w „filmach rozrachunkowych”, których główna część akcji rozgrywa się współcześnie. W utworach takich jak Enen (2009) Feliksa Falka, Kret (2010) Rafaela Lewandowskiego czy w Rysa (2008) Michała Rosy pojawiają się cienie przeszłości, rzutujące w sposób istotny na współczesność. Najwyraźniej jest to widoczne w polsko-francuskiej produkcji z 2010 roku, w której okazuje się, jak wielką władzę nad rzeczywistością wciąż posiadają byli urzędnicy komunistycznego reżimu. Grany przez Wojciecha Pszoniaka Stefan Garbarek, były kapitan SB, wciąż decyduje o losie zwerbowanego w latach osiemdziesiątych działacza związkowego. To od jego zeznań zależy, czy Zygmunt Kowal (Marian Dziędziel) uniknie infamii, czy zachowa otaczający go szacunek otoczenia, czy będzie potrafił spojrzeć w oczy rodzinie i przyjaciołom, czy też skrywana przez wiele lat tajemnica ujrzy wreszcie światło dzienne. Nieco bardziej pogłębiony psychologicznie obraz rozpadu więzi rodzinnych zaprezentował Michał Rosa, choć wyreżyserowana przez niego Rysa również bazuje na esbeckich materiałach, które, wychodząc po latach na jaw, niszczą małżeństwo państwa Żółwieńskich.

\section{5. ŻYCIE CODZIENNE}

Filmy prezentujące rzeczywistość lat osiemdziesiątych, które nie są biografiami i nie mają charakteru ściśle rozrachunkowego, tworzyłaby grupa filmów nieco bardziej różnorodnych. Z jednej strony w tej grupie mieściłby się choćby Dom zły (2009) Wojciecha Smarzowskiego, w którym omawiana dekada jest jedynie tłem do dość uniwersalnej refleksji na temat zła tkwiącego w ludziach. 
Pomimo komediowego sztafażu również Sztos 2 (2011) Olafa Lubaszenki nie przynosi radosnej wizji czasów stanu wojennego. Choć jest to kolejna opowieść o wielkim skoku, to trudno w tym dziele dostrzec sentymentalny powrót do przeszłości, który był jedną z podstaw sukcesu pierwszej części, nakręconej w roku 1997, a opowiadającej o latach siedemdziesiątych. Bohaterowie sequela uwikłani zostali w grę polityczną, ich przeciwnikami są SB-ecy i tępi milicjanci, rzeczywistość jest niezwykle ponura, a - co może najważniejsze - scenariusz filmu i padające z ekranu żarty niezbyt dopracowane.

Innym filmem, mieszczącym się w tej kategorii, byłaby nostalgiczna podróż do czasów młodości, jaką zafundował widzom Jacek Borcuch w utworze Wszystko, co kocham (2009). Choć akcja filmu jest osadzona w bardzo konkretnym czasie historycznym wprowadzenie stanu wojennego i polityczne konteksty dekady odgrywają w nim istotną rolę, to jednak jest to przede wszystkim dzieło, które przez analogię do terminu literaturoznawczego można by nazwać „Bildungsfilm” - filmem o dojrzewaniu. Uczynienie głównym protagonistą osiemnastoletniego Janka, którego bardziej niż czołgi na ulicach interesuje granie w punkowej kapeli, inicjacja seksualna ze znudzoną życiem starszą sąsiadką czy miłość do szkolnej koleżanki, sprawiają, że czasy sprzed trzech dekad nabierają innego znaczenia. Borcuch (rocznik 1970) przypomina bowiem w swym filmie, że okres schyłkowego PRL-u to nie tylko „walka z komuną”, ale i okres rozkwitu muzyki rockowej, popularności Bruce’a Lee czy potańcówek w szkolnych salach dekorowanych obowiązkowo siatką maskującą. Obecna jest więc w tym filmie - najbardziej chyba wprost wyrażona, jeśli weźmiemy pod uwagę omawiane w artykule dzieła - nostalgia za latami młodości znacznej części widzów, która przypadała na czasy może i szare i nieciekawe, ale te, gdy byliśmy młodzi, pełni ideałów i gdy przeżywaliśmy pierwsze erotyczne zauroczenia.

Co ciekawe w zasadzie tylko dwa filmy przynoszą dalece odmienną wizję lat osiemdziesiątych i oba prezentują perspektywę kobiecą. Zdecydowanie najbardziej optymistyczny obraz lat osiemdziesiątych, jaki możemy odnaleźć w filmach z dekady 2007-2016, a który pojawia się w Ile waży koń trojański? (2008) Juliusza Machulskiego wynika zapewne z komediowego charakteru samej opowieści i z umieszczenia akcji w roku 1987, ale - w moim odczuciu - niebagatelny wpływ na to ma także uczynienie główną postacią żeńskiej protagonistki. Omawiany film reżysera kultowej Seksmisji, jak pisał Artur Majer, „przewrotnie prezentuje wszystkich mężczyzn jako nieświadomych, uległych, niemal biernych, a wszystkie kobiety (może oprócz epizodycznej matki głównej bohaterki) - jako aktywne (Zosia ma rzecz jasna pozycję szczególną, mając nad wszystkimi przewagę zarówno samowiedzy, jak i wiedzy historycznej). 
Co więcej, nawet pozornie negatywne postaci kobiece w swoim działaniu i istnieniu »na przekór « głównej bohaterce, mają swoje racje i ostatecznie wymiar pozytywny. (...) Tymczasem mężczyźni są konsekwentnie pokazani jako słabi” (2014, s. 309). Takie rozłożenie akcentów genderowych pozwala na odejście od „Wielkiej Historii”, która determinowała niemal wszystkie inne filmy prezentujące męski punkt widzenia. Oczywiście w roku 1987 PRL nie miał już tak złowrogiego oblicza, jak w początkach dekady, jednak niedogodności, jakich doświadcza bohaterka, która przenosi się w czasie z roku 1999, mają charakter raczej obyczajowo-technologiczny, a nie polityczny. Zosia (Ilona Ostrowska) kilka razy powtarza, że zapomniała, ,jacy wy [mając na myśli czasy, do których się przeniosła - A.L.] jesteście zacofani”. Mówi tak, gdy nie może zameldować się w hotelu, ponieważ ma warszawski meldunek, gdy w restauracji nie może zapłacić kartą czy zadzwonić do kogoś na komórkę. Polityka i komunistyczny system nie odgrywają w tym filmie prawie żadnej roli, są nieistotne. Ważne jest odnalezienie miłości, ocalenie ukochanej babci, doprowadzenie do poczęcia dziecka. Dość paradoksalnie, bo wciąż odnosząc się do narzuconego przez system patriarchalny wzorca, sprawy prywatne (przypisywane przez ten paradygmat - kobietom) są znacznie istotniejsze niż „męskie” sprawy publiczne.

Niezwykle podobne uwagi można by odnieść do filmu Córki dansingu (2015) Agnieszki Smoczyńskiej. Ta hybrydyczna gatunkowo historia dwóch syren, które pojawiają się w Polsce lat osiemdziesiątych prezentuje bowiem zupełnie pozbawioną wtrętów historycznych wersję rzeczywistości ostatniej dekady PRL-u. Jak zauważają Paulina Pohl i Krystyna Weiher-Sitkiewicz: „Tłem historii syrenek jest polska rzeczywistość lat osiemdziesiątych. Trudno jednak utrzymywać, że Córki... są filmem historycznym. Opowieść zakotwiczona zostaje w określonej dekadzie, ale bardziej niż na przedstawieniu polskich realiów po stanie wojennym skupia się na reinterpretacji wspomnień i wyobrażeń tamtej epoki. Urodzeni pod koniec lat siedemdziesiątych Smoczyńska i Robert Bolesto [autor scenariusza do filmu, a także scenarzysta Hardkor Disco i Ostatniej rodziny - A.L.] posługują się nostalgiczną konstrukcją filmowego świata, pokazując nocne życie stolicy, wypełnionej muzyką disco i światłami neonów” (2016, s. 229).

\section{PODSUMOWANIE}

„Jaruzelonostalgia”, którą możemy obserwować w kinie ostatniej dekady, ma więc wymiar podwójny. Z jednej strony ma charakter osobistego powrotu do czasów młodości, które być może i przypadły na dekadę pozbawioną polityczno- 
-społecznego uroku, ale jednak definiującą życie wielu twórców, którym wtedy przyszło dorastać. Co znamienne, to właśnie w dziełach młodych reżyserów częściej można odnaleźć obraz Polski pozbawiony przytłaczającego politycznie charakteru. Pomimo różnic Bogowie, Wszystko, co kocham, Ostatnia rodzina czy Córki dancingu prezentują obraz rzeczywistości końcówki PRL-u w zdecydowanie inny sposób niż dzieła reżyserów urodzonych w latach sześćdziesiątych lub wcześniej. Polska to kraj nie tyle komunistycznego reżimu, ile obszar dominacji zacofanego technologicznie patriarchatu, w którym (co młodsi twórcy mniej lub bardziej świadomie krytykują) władza „starych mężczyzn” jest wszechobecna i niezaprzeczalna. Paradoksalnie wydaje się, że mógł to być także - zapewne równie nieświadomy - powód, dla którego reżyserzy (mężczyźni!) starszego pokolenia równie chętnie powracali do tamtej dekady. W ich interpretacji był to bowiem dość przerażający czas, gdy wszystko było sprawą polityczno-publiczną, ale jednocześnie był to okres, w którym kobiety dość potulnie wpisywały się w rolę ,opiekunki domowego ogniska” i „pocieszycielki strudzonego wojownika”. Okres, gdy symboliczna i polityczna władza mężczyzn była niezaprzeczalna, czas, za którym - pomimo fatalnych warunków ekonomiczno-społecznych - też tęsknią i który przywołują nostalgicznie w swoich filmach.

\section{Bibliografia}

Bell, D. (2014). Kulturowe sprzeczności kapitalizmu. Tłum. S. Amsterdamski. Warszawa: Wydawnictwo Fundacja Altheia.

Gluza, Z. (red.). (2014). W stanie. Zbiorowy dziennik stanu wojennego. Warszawa: Ośrodek KARTA.

Głowacki, J. (2013). Przyszłem, czyli jak pisałem scenariusz o Lechu Wałęsie dla Andrzeja Wajdy. Warszawa: Świat Książki.

Klimek, K. (2012). Powtórki z rozrywki, czyli hollywoodzka retromania. Ekran-y, 5 (9), s. 4-11.

Kornacki, K. (2017). Tworzenie obrazu przeszłości w trylogii robotniczej Andrzeja Wajdy. Przestrzenie Teorii, 27, s. 77-91.

Łukasiewicz, J. (2008). Twórca w systemie komunistycznym. W: R. Klementowski, S. Ligerski (red.), Artyści a Służba Bezpieczeństwa. Aparat bezpieczeństwa wobec środowisk twórczych. Materiały pokonferencyjne (s. 13-23). Wrocław: Oddział Instytutu Pamięci Narodowej Komisji Ścigania Zbrodni przeciwko Narodowi Polskiemu.

Majer, A. (2014). Kino Juliusza Machulskiego. Bielsko-Biała: Wydawnictwo Kwieciński. Orzechowski, H. (2016). „Jack Strong” wcale nie taki mocny. Pobrane z: http://www. newsweek.pl/kultura/jack-strong-recenzja-pasikowski-kuklinski-newsweekpl,artykuly,280317,1.html. 
Pohl, P., Weiher-Sitkiewicz, K. (2016). Jak robić w Polsce filmy, których nikt nie robi? Przypadek „Córek dancingu”. Panoptikum, 16, s. 228-243.

Popielecki, J. (2016). Bo wszyscy Beksińscy to jedna rodzina. Pobrane z: https://www. filmweb.pl/review/Bo+wszyscy+Beksi\%C5\%84scy+to+jedna+rodzina-19136.

Przylipiak, M. (2018). Szofer Wałęsy. Studia Filmoznawcze, 39, s. 107-126.

Syska, R. (2012). Reaganomatoretro, czyli czekając na herosa. Ekran-y, 5 (9), s. 15-17.

Światek, R. (2009). Byle jaka hagiografia. Pobrane z: http://www.rp.pl/artykul/268508-Byle-jaka-hagiografia-.html. 